\title{
ANALISIS PENENTUAN ZONASI PEMUKIMAN RISIKO BENCANA TANAH LONGSOR BERBASIS SISTEM INFORMASI GEOGRAFIS: STUDI KASUS KECAMATAN GEDANGSARI, KABUPATEN GUNUNG KIDUL, DAERAH ISTIMEWA YOGYAKARTA
}

\author{
Mohammad Abdul Khafid \\ Progam Studi Teknik Lingkungan, Fakultas Teknologi Mineral \\ Universitas Pembangunan Nasional "Veteran" Yogyakarta \\ "Email : abdulkhafid925@gmail.com
}

\begin{abstract}
ABSTRAK
Indonesia merupakan negara yang sering terjadi bencana hidrometeorologi di antaranya adalah tanah longsor. Kecamatan Gedangsari, Kabupaten Gunungkidul, Yogyakarta, termasuk kabupaten yang sangat tinggi berpotensi terjadinya tanah longsor. Hal ini di buktikan dengan banyaknya kejadian gerakan massa tanah ataupun batuan terutama saat musim hujan dan telah menimbulkan kerusakan fisik atau bahkan sampai dengan korban jiwa. Gedangsari Terletak pada ketinggiam 120 - 800 mdpl dengan kemiringan lereng datar - sangat curam yang memungkinkan terjadinya bencana longsor. Perlunya dilakukan penyidikan awal untuk memetakan daerah potensi rawan longsor sehingga dapat menentukan pula daerah pemukiman rawan longsor, selanjutnya dapat menjadi rujukan dalam penataan wilayah dan penyiapan mitigasinya. Metode yang digunakan dalam penelitian ini menggunakan pembobotan dengan parameter, berupa: data kelerengan, data curah hujan, data zona aktif struktur, data jenis batuan, dan data penggunaan lahan yang nantinya diolah menggunakan perangkat lunak Arc. GIS 10.2. Hasil dari peta potensi longsor ini selanjutnya dianalisis dengan peta pemukiman penduduk, sehingga menghasilkan peta zonasi pemukiman rawan longsor. Dengan hasil ini diharapkan dapat membantu pemerintah untuk melakukan penanganan bencana tanah longsor lebih cepat, sehingga dampak yang ditimbulkan nantinya tidak mengakibatkan kerugian yang besar dan dapat juga di gunakan sebagai perencanaan pembangunan wilayah.
\end{abstract}

Kata Kunci : Pembobotan, Tanah longsor, Mitigasi, Kecamatan Gedangsari

\section{ABSTRACT}

Indonesia is a country that is often a disaster hidrometeorologycal of these are landslide. Gedangsari Districts, Gunungkidul Region, Yogyakarta, belong to region that are very high potential of landslides. It is attested, with many mass movements of soil or rock especially during the rainy season and have caused physical damage or even to cause casualties. Gedangsari is placed at 120 - 800 masl with flat - very steep slope allows the occurences of landslides. The preliminary investigation is necessary to map the landslide potential area so it can determine the landslide-prone residences, then can be a reference in the arrangement of the region and preparation of mitigation. Scoring method is used in this study, the parameters are: slopes data, rainfall data, active geology structure zone data, rock type data, and land use data, then processed with ArcGIS 10.2. The result of landslide-prone map is overlaid with population map resulting map that zoning residence landslide-prone. With this result, it is hoped the government can use it to handle landslides hazard better, so the impacts will not resulting a big lossesand can be used of planning regional development.

Keyword : Landslide, Scoring, Mitigation, Gedangsari districts

\section{PENDAHULUAN}

\subsection{Latar Belakang}

Indonesia merupakan negara yang terdapat pertemuan tiga lempeng tektonik aktif yang geografis rawan terjadi bencana alam. Menurut UU no. 24 tahun 2007, menyebutkan bahwa, bencana adalah peristiwa atau rangkaian peristiwa yang mengancam dan mengganggu kehidupan dan penghidupan masyarakat yang disebabkan, baik oleh faktor alam dan/atau faktor nonalam maupun faktor manusia sehingga mengakibatkan timbulnya korban jiwa 
manusia, kerusakan lingkungan, kerugian harta benda, dan dampak psikologis. Sedangkan bencana hidrometeorologi adalah bencana yang di sebabkan oleh adanya perubahan iklim. Menurut Nugroho (2015), Sekitar $98 \%$ dari total kejadian bencana alam pertahunnya adalah bencana hidrometeorologi seperti banjir, tanah longsor, kekeringan, kebakaran hutan dan lahan serta gelombang laut. Sejak tahun 2010 hingga tahun 2014 bencana hidrometeorologi telah terjadi lebih dari 1900 kali dengan ratarata per tahunnya sebanyak 1124 kali. Bencana yang mendominasi adalah tanah longsor dengan total kejadian sebanyak 3032 kali yang menyebabkan korban jiwa atau meninggal sebanyak 2326 jiwa.

Kabupaten Gunung Kidul merupakan kabupaten dengan lahan yang kondisinya relatif rawan dan labil terhadap gerakan massa tanah atau batuan. Menurut BNPBD Gunung Kidul (2001), kejadian bencana tanah longsor sudah sering terjadi di beberapa kecamatan, tak terkecuali Kecamatan Gedangsari, yang merupakan salah satu kecamatan di Gunung Kidul yang rawan terjadi tanah longsor. Mengingat kondisin daerah Kecamatan Gedangsari, Gunung Kidul yang secara geomorfologi terletak pada ketinggiam $120-800 \mathrm{mdpl}$ dengan kemiringan lereng datar - sangat curam yang memungkinkan terjadinya bencana longsor. Kecamatan Gedangsari terdiri dari tujuh desa yang hampir seluruhnya sering terjadi bencana tanah longsor yang mengakibatkan korban jiwa dan kerugian material. Beberapa kejadian tanah longsor di Kecamatan Gedangsari dalam lima tahun terakhir adalah sebagai berikut:

Tabel 1. Kejadian Tanah Longsor di Kecamatan Gedangsari Tahun 2011 - Tahun 2015

\begin{tabular}{|l|c|c|c|}
\hline No & Tahun & $\begin{array}{c}\text { Jumlah } \\
\text { Kejadian }\end{array}$ & $\begin{array}{c}\text { Lokasi Kejadian / } \\
\text { Desa }\end{array}$ \\
\hline 1 & 2011 & 2 & Watugajah, Mertelu, \\
\hline 2 & 2012 & 11 & $\begin{array}{c}\text { Watugajah, Mertelu, } \\
\text { Tegalrejo }\end{array}$ \\
\hline 3 & 2013 & 81 & $\begin{array}{c}\text { Hargomulyo, } \\
\text { Mertelu, Ngalang, } \\
\text { Serut, Watugajah }\end{array}$ \\
\hline 4 & 2014 & 29 & $\begin{array}{c}\text { Hargomulyo, } \\
\text { Mertelu, Sampang }\end{array}$ \\
\hline 5 & 2015 & 13 & Watugajah \\
\hline
\end{tabular}

Sumber : BPBD Kabupaten Gunung Kidul Tahun 2016.

Dengan adanya bencana tanah longsor yang terjadi dengan di dukung adanya titik-titik rawan tanah longsor di Kecamatan Gedangsari yang digunakan sebagai tempat tinggal oleh masyarakat setempat, maka perlu dilakukan studi tentang persebaran daerah rawan longsor untuk menangani daerah yang berpotensi bencana tanah longsor. Dengan adanya peta persebaran pemukiman potensi rawan longsor ini di harapkan dapat di gunakan oleh pemerintah maupun oleh para pihak (stakeholder) untuk penanggulangan dan perencanaan pembangunan di wilayah Kecamatan Gedangsari.

\subsection{Perumusan Masalah}

Adapun rumusan masalah dalam penelitian ini adalah :

1. Bagaimana potensi pemukiman rawan bencana tanah longsor di Kecamatan Gedangsari menggunakan pendekatan sistem informasi geografis dan model dari Puslittanak tahun 2004 yang telah di sesuaikan dengan karakteristik daerah penelitian?

2. Apa saja faktor yang mempengaruhi tingkat kerentanan tanah longsor di Kecamatan Gedangsari ?

\subsection{Tujuan}

Penelitian ini bertuuan untuk mengetahui peta potensi persebaran pemukiman yang rawan terhadap bencana tanah longsor yang berada di Kecamatan Gedangsari, Kabupaten Gunungkidul. Di harapkan dengan adanya peta potensi pemukiman rawan tanah longsor, dapat menjadi rekomendasi bagi pemerintah setempat sebagai tindakan mitigasi bencana maupun perencanaan pembangunan wilayah.

\subsection{Dasar Teori}

Tanah longsor merupakan salah satu bencana alam yang berasal dari natural hazardz (geological), yaitu gerakan massa tanah atau batuan maupun percampuran antara keduanya, yang menuruni lereng yang di akibatkan oleh ketidakstabilan tanah atau batuan yang menyusun lereng tersebut (Nurjanah, 2011). Menurut Paimin dkk. (2009), ada beberapa faktor yang menyebabkan rentannya tanah longsor di 
antaranya adalah kondisi lereng yang terjal atau curam, adanya bidang gelincir yang kedap air di lapisan bawah permukaan tanah dan terdapat kondisi air tanah di atas lapisan kedap jenuh air. Prinsipnya tanah longsor dapat terjadi jika gaya pendorong pada lereng lebih besar dari pada gaya penahannya. Gaya penahan atau faktor pengontrolnya pada umumnya di pengaruhi oleh kekuatan batuan dan kepadatan tanah, sedangkan gaya pendorongnya di pengaruhi oleh besar sudut lereng dan beban pada lereng. Sedangkan menurut PVMBG (2011), terdapat faktor yang menyebabkan tanah longsor di antaranya adalah curah hujan, kemiringan lereng, ketebalan tanah, pelapukan batuan, tata guna lahan, getaran, pembebanan lereng, dan pengikisan tanah. Secara umum terdapat beberapa tipe tanah longsor, di antaranya : longsoran translasi, longsoran rotasi, pergerakan blok, rockfall atau runtuhan batu, creep atau rayapan tanah, dan aliran bahan rombakan. Namun beberapa contoh kejadian tanah longsor atau longsoran yang terdapat di berbagai daerah di indonesia yaitu jenis longsoran translasi dan longsoran rotasi. Namun, jenis longsoran yang paling banyak memakan korban jiwa manusia adalah aliran bahan rombakan yang biasanya membawa material bongkah. Tanah longsor terdapat beberapa tipe atau jenis di antaranya adalah longsoran translasi, longsoran rotasi, pergerakan blok, reruntuhan batu, rayapan tanah, dan aliran bahan rombakan.

Sistem Informasi Geografis menurut Demers (1997) yakni komponen kombinasi dari perangkat keras, perangkat lunak, data geografis dan sumber daya manusia yang satu sama lain terintegrasi secara efektif yang dapat di gunakan untuk memasukkan, menyimpan, memperbaiki, mempebaharui, mengelola, memanipulasi, mengintegrasikan, menganalisa, dan menampilkan data dalam suatu informasi berbasis spasial atau geografis. Komponen dasar dalam SIG terdiri dari empat sistem yaitu:

1. Data masukan (Input)

Input atau masukan ini di gunakan untuk sering di gunakan untuk menyiapkan, mengumpulkan data spasial maupun data atribut serta mengubahnya sesuai format sistem informasi geografis.

2. Data keluaran (Reporting)
Data dari spasial tersebut biasanya dapat di sajikan dalam berbagai jenis data, misalnya bentuk softcopy maupun hardcopy, contohnya : grafik, tabel, peta, koordinat dan lain-lain.

3. Data Storage and Retrieval

Komponen storage berfungsi sebagai penyimpanan dan mengorganisasikan data spasial dan data atribut dalam basis data sehingga mudah jika di update.

4. Data Analysis and Manipulation :

Data analysis and manipulation dapat di gunakan dalam menentukan maupun mengubah suatu data informasi atau data analisis yang dihasilkan oleh data spasial serta melakukan pemodelan atau manipulasi sehingga di dapatkan informasi yang di harapkan (Demers, 1997 dalam Prahasta, 2001).

\section{METODE PENELITIAN}

Metode penilaian atau skoring pemukiman risiko tanah longsor yang digunakan dalam penelitian ini menggunakan pembobotan (skoring) yang mengacu pada Puslittanak tahun 2004 yang di sesuaikan dengan karakteristik daerah penelitiannya. Menurut model Puslittanak (2004), parameter kelerengan, jenis batuan, struktur geologi, penggunaan lahan di beri bobot $20 \%$, faktor curah hujan bobot $30 \%$, sedangkan jenis tanah di beri bobot $10 \%$.

Berdasarkan penjelasan tersebut, maka untuk mengetahui tingkat kerawanan longsor, di gunakan rumus sebagai berikut:

Skor total $=0,3 \mathrm{CH}+0,2 \mathrm{KL}+0,2 \mathrm{JB}+$ 0,2 SG + 0,2 PL + 0,1 JT

Keterangan:

$$
\begin{array}{ll}
\mathrm{CH} & =\text { Curah Hujan } \\
\mathrm{KL} & =\text { Kemiringan Lereng } \\
\mathrm{JB} & =\text { Jenis Batuan } \\
\mathrm{SG} & =\text { Struktur Geologi } \\
\mathrm{PL} & =\text { Penggunaan Lahan } \\
\mathrm{JT} & =\text { Jenis Tanah }
\end{array}
$$

Data tersebut kemudian di olah dengan menggunakan software Arc.GIS10.2. Adapun untuk tahapan metodologi penelitian secara umum dapat di lihat pada (Gambar 1). 


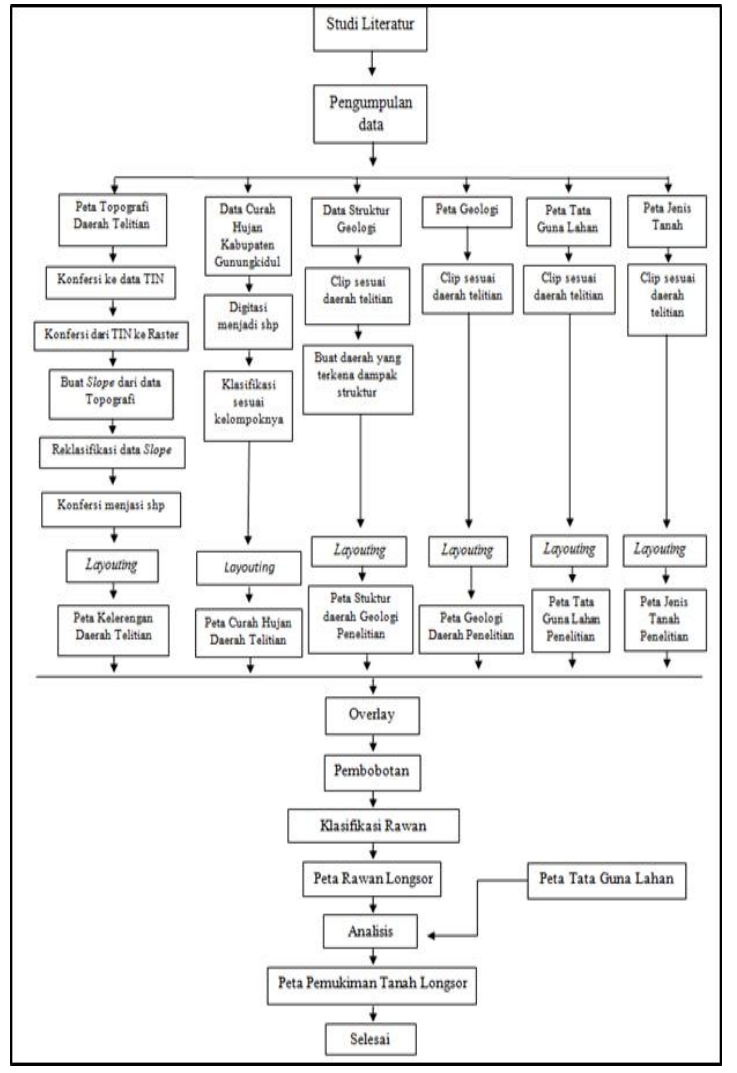

Gambar 1. Kerangka Alur Penelitian.

\subsection{Waktu dan Lokasi}

Kajian literatur dan survey lokasi penelitian di lakukan di seluruh Kecamatan Gedangsari, rentan waktu bulan September - Desember 2018. Secara administrasi lokasi penelitian berada di kecamatan Gedangsari, kabupaten Gunungkidul, Daerah Istimewa Yogyakarta. Secara administrasi Kecamatan Gedangsari terdapat tujuh desa dengan luas wilayah 68,4 $\mathrm{km} 2$. Secara sistem koordinat UTM terletak pada X: 455200-460200 dan Y: $9133300-$ 9138300. Lokasi penelitian ini berbatasan dengan kabupaten Klaten di bagian utara dengan kondisi daerah telitian memiliki topografi yang berbukit-bukit.

\subsection{Alat dan Data Penelitian}

Peralatan yang di gunakan terdiri dari perangkat keras dan perangkat lunak yaitu:

a. Perangkat Keras

1. Laptop Dell 3476 (Intel ${ }^{\circledR}$ Core TM $\mathrm{i3}$ 7020u CPU@2.30 GHz, RAM 4.00 GB

\section{GPS}

3. Kamera

\section{Kompas Geologi dan Bor Tanah}

b. Perangkat Lunak

1. Arc Mao 10.2

2. Microsoft Office 2016

3. Corel Draw 7

Data yang di gunakan dalam penelitian ini adalah :

a. Data curah hujan Kabupaten Gunungkidul

b. Data kejadian tanah longsor dari BPBD Kabupaten Gunungkidul

c. Citra DEM SRTM Daerah Istimewa

Yogyakarta

d. Peta Geologi Lembar Yogyakarta

e. Peta penggunaan lahan Kabupaten Gunungkidul dalam.

f. Peta jenis tanah Kabupaten Gunung kidul

\section{HASIL DAN PEMBAHASAN}

\subsection{Peta Kelerengan Daerah Penelitian}

Peta kemiringan lereng didapat dari proses pembuatan slope menggunakan data topografi dari citra DEM. Data citra DEM yang di gunakan yakni Citra DEM SRTM Provinsi Daerah Istimewa Yogyakarta. Setelah di analisis di dapatkan Kondisi daerah penelitian memiliki topografi berupa perbukitan dengan kelas kelerengan yaitu kelerengan datar $\left(0^{\circ}-6^{\circ}\right)$,kelerengan landai $\left(6^{\circ}\right.$ $\left.-15^{\circ}\right)$,kelerengan agak curam $\left(15^{\circ}-25^{\circ}\right)$, kelerengan curam $\left(25^{\circ}-45^{\circ}\right)$, dan kelerengan sangat curam $\left(>45^{\circ}\right)$. Kondisi topografi yang di dominasi terjal atau curam menjadi salah satu penyebab atau faktor pendorong terjadinya tanah longsor. Skala peta yang di gunakan yakni skala 1 : 25.000. Adapun untuk hasil peta kelerengan dan skor pembobotannya secara umum dapat di lihat pada (Gambar 2) dan (Tabel 2). 




Gambar 2. Peta Kelas Kelerengan Daerah Kecamatan Gedangsari dan sekitarnya.

Tabel 2. Nilai Pembobotan Kelerengan Kecamatan Gedangsari dan Sekitarnya

\begin{tabular}{|c|c|c|}
\hline No & Klasifikasi Kelerengan & Nilai (skor) \\
\hline 1 & Sangat Curam $\left(>45^{\circ}\right)$ & 5 \\
\hline 2 & Curam $\left(25^{\circ}-45^{\circ}\right)$, & 4 \\
\hline 3 & Agak Curam $\left(15^{\circ}-25^{\circ}\right)$ & 3 \\
\hline 4 & Landai $\left(6^{\circ}-15^{\circ}\right)$ & 2 \\
\hline 5 & Datar $\left(0^{0}-6^{\circ}\right)$ & 1 \\
\hline
\end{tabular}

Berdasarkan klasifikasi tabel yang telah di buat,dapat diketahui bahwa kelerengan didaerah telitian sangat bervariasi dari kelerengan datar hingga kelerengan sangat curam.Tingkat kelerengan yang curam sampai dengan sangat curam berada di wilayah Kecamatan Gedangsari dan Kecamatan Nglipar. Sedangkan pada daerah utara terutama di Kecamatan Gantiwarno, Kecamatan Wedi, dan Kecamatan Bayat tingkat kelerengannya relatif datar sampai dengan landai.

\subsection{Peta Jenis Batuan Daerah Penelitian}

Jenis batuan merupakan komponen penting untuk mengetahui persebaran batuan dan genesa batuan pada suatu wilayah tertentu yang dapat mencirikan resistensi dan kestabilan batuan. Batuan di bagi menjadi empat jenis yaitu, batuan sedimen, batuan beku, batuan metamorf, dan batuan piroklastik. Sifat fisik batuan secara umum berbeda-beda, hal ini di pengaruhi oleh beberapa faktor yaitu, struktur, tekstur, kekar, kandungan mineral dan sementasinya. Perbedaan jenis batuan merupakan salah satu parameter penyebab adanya tanah longsor karena batuan memiliki porositas dan permeabilitas yang berbeda-beda. Hal itulah yang menjadi faktor dalam pembobotan batuan yang di kelompokkan berdasarkan tingkat resistensi dan kestabilan batuannya. Adapun untuk hasil peta kelerengan dan skor pembobotannya secara umum dapat di lihat pada (Gambar 3) dan (Tabel 3).

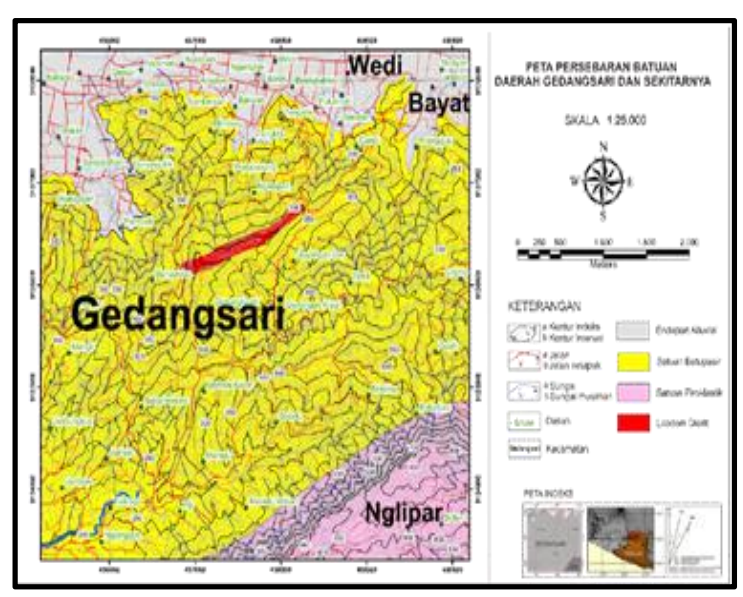

Gambar 3. Peta Persebaran Batuan Daerah Kecamatan Gedangsari dan sekitarnya

Tabel 3. Nilai Pembobotan Jenis Batuan Kecamatan Gedangsari dan Sekitarnya

\begin{tabular}{|c|c|c|}
\hline No & Jenis Batuan & Nilai (skor) \\
\hline 1 & Litodem Diorit & 1 \\
\hline 2 & Satuan Piroklastik & 2 \\
\hline 3 & Satuan Batupasir & 3 \\
\hline 4 & Endapan Alluvial & 4 \\
\hline
\end{tabular}

Berdasarkan klasifikasi tabel diatas maka dapat diketahui bahwa daerah penelitian terdapa tempat jenis batuan yaitu Endapan Alluvial, Batu pasir, Piroklastik, dan Litodem Diorit. Batuan yang dominan pada daerah telitian adalah batu pasir.

\subsection{Peta Struktur Geologi Daerah Penelitian}

Keterdapatan struktur geologi pada suatu wilayah dapat di cirikan dengan adanya kenampakan blok patah dan timbul banyak rekahan - rekahan pada batuan, yang merupakan bidang breksiasi atau hancuran. Daerah yang terdapat struktur geologi seperti kekar maupun sesar akan sangat berpotensi tanah longsor. Data struktur geologi pada dearah penelitian terdapat tiga jens struktur geologi yaitu, Zona Non-Struktur, Zona Struktur Terdampak, dan Zona Struktur 
Utama.. Adapun untuk hasil peta kelerengan dan pembobotannya secara umum dapat di lihat pada (Gambar 4) dan (Tabel 4).

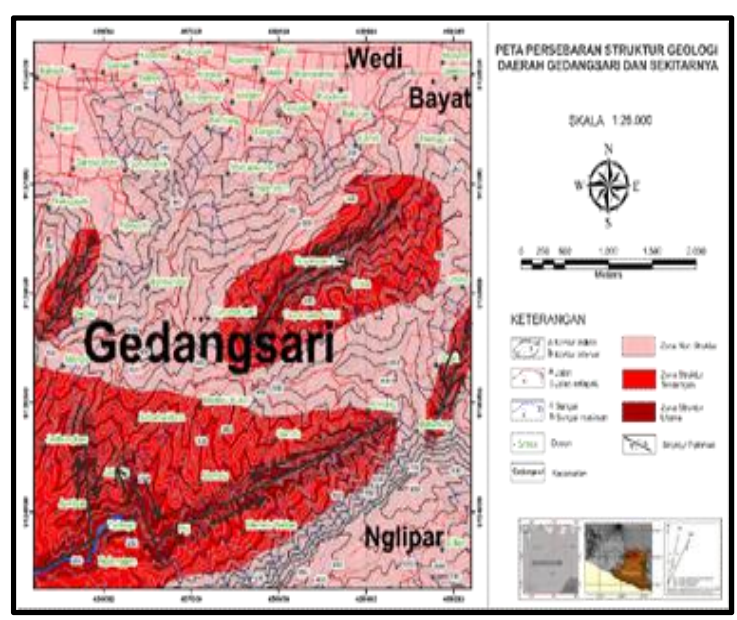

Gambar 4. Peta Persebaran Struktur Geologi Daerah Kecamatan Gedangsari dan sekitarnya

Tabel 4. Nilai Pembobotan Struktur Geologi Kecamatan Gedangsari dan Sekitarnya

\begin{tabular}{|c|c|c|}
\hline No & Zona Struktur & Nilai (skor) \\
\hline 1 & Zona Struktur Utama & 5 \\
\hline 2 & Zona Struktur Terdampak & 3 \\
\hline 3 & Zona Non Struktur & 1 \\
\hline
\end{tabular}

Berdasarkan klasifikasi hasil tabel dan peta persebaran struktur geologi di daerah penelitian, dapat di ketahui bahwa daerah Kecamatan Gedangsari di dominasi banyaknya zona struktur utama. Sedangkan daerah Kecamatan Wedi dan Kecamatan Bayat hampir seluruhnya merupakan zona struktur non aktif yang relatif aman dari gerakan massa tanah atau tanah longsor.

\subsection{Peta Penggunaan Lahan Daerah Penelitian}

Penggunaan lahan merupakan setiap aktivitas manusia terhadap sumber daya lahan yang dapat bersifat menetap maupun pergiliran, dalam rangka memenuhi kebutuhan hidupnya. Secara umum dampak penggunaan lahan bisa positif maupun negatif, tergantung dari aspek pengelolaannya. Dampak dari penggunaan lahan yang tidak sesuai di antaranya adalah tanah longsor. Secara umum peran penutup lahan berpotensi yang dapat memicu terjadinya tanah longsor. Adapun untuk hasil peta kelerengan dan pembobotannya secara umum dapat di lihat pada (Gambar 5) dan (Tabel 5).

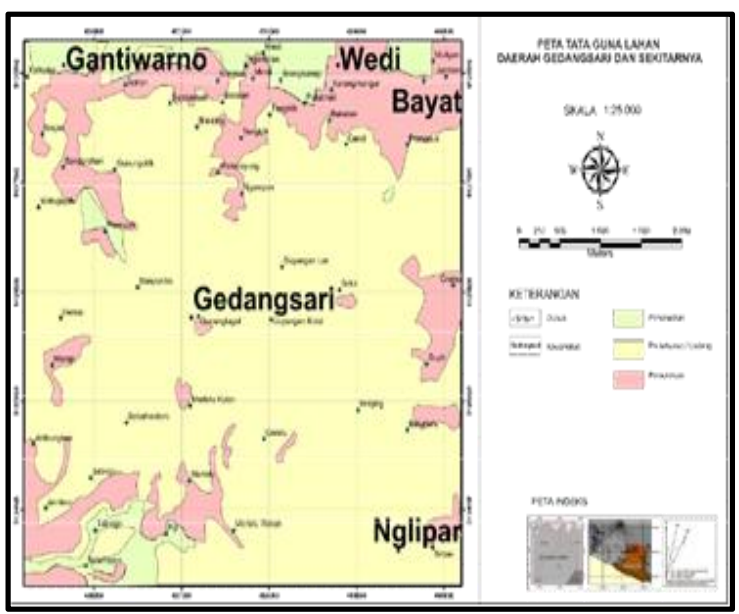

Gambar 5. Peta Tata Guna Lahan Daerah Kecamatan Gedangsari dan sekitarnya

Tabel 5. Nilai Pembobotan Tata Guna Lahan Kecamatan Gedangsari dan Sekitarnya

\begin{tabular}{|c|c|c|}
\hline No & Tata Guna Lahan & $\begin{array}{c}\text { Nilai } \\
\text { (skor) }\end{array}$ \\
\hline 1 & Pemukiman & 3 \\
\hline 2 & $\begin{array}{c}\text { Perkebunan atau } \\
\text { Ladang }\end{array}$ & 2 \\
\hline 3 & Persawahan & 1 \\
\hline
\end{tabular}

Berdasarkan gambar diatas maka diketahui bahwa daerah penelitian terdapat tiga jenis tata guna lahan yaitu Persawahan, Perkebunan dan Pemukiman. Penggunaan lahan yang dominan pada daerah Kecamatan Gedangsari adalah perkebunan atau ladang sedangkan pemukiman mempunyai pola tata guna lahan yang menyebar.

\subsection{Peta Curah Hujan Daerah Penelitian}

Manfaat penelitian ini selain untuk memberikan gambaran mengenai keakuratan Salah satu faktor pemicu terjadinya tanah longsor yaitu curah hujan, yang mana akan dapat mempengaruhi kestabilan tanah. Berdasarkan data curah hujan dari RTRW Kabupaten Gunungkidul, wilayah Kecamatan Gedangsari termasuk tinggi dari kecamatan sekitarnya yaitu berkisar antara $1500-2000$ $\mathrm{mm} /$ tahun. Faktor kondisi curah hujan seperti intensitas dan penyebaran distribusi hujanjuga dapat menentukan titik potensi wilayah yang rawan terjadi tanah longsor. Adapun untuk hasil peta kelerengan dan pembobotannya secara umum dapat di lihat pada (Gambar 6) dan (Tabel 6). 


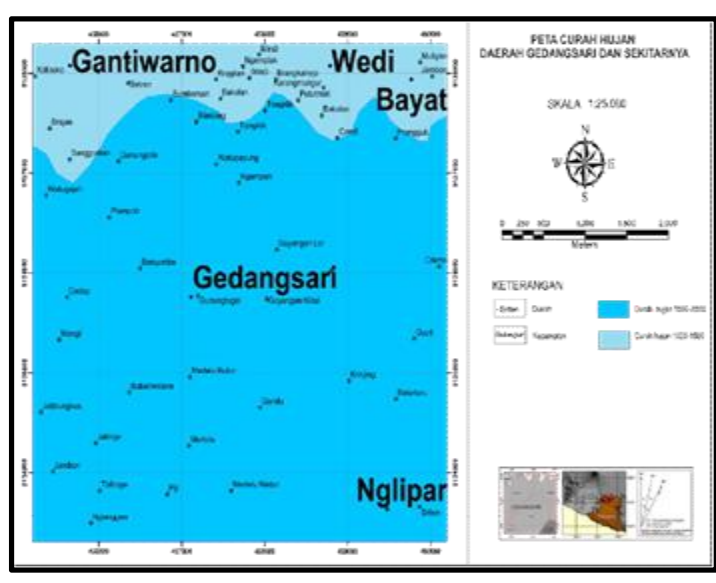

Gambar 6. Peta Curah Hujan Daerah Kecamatan Gedangsari dan sekitarnya

Tabel 6. Nilai Pembobotan Curah Hujan Kecamatan Gedangsari dan Sekitarnya

\begin{tabular}{|c|c|c|}
\hline No & Besar Curah Hujan & $\begin{array}{c}\text { Nilai } \\
\text { (skor) }\end{array}$ \\
\hline 1 & $\begin{array}{c}\text { Curah Hujan } 1500-2000 \\
\text { mm/tahun }\end{array}$ & 3 \\
\hline 2 & $\begin{array}{c}\text { Curah Hujan } 1000-1500 \\
\text { mm/tahun }\end{array}$ & 1 \\
\hline
\end{tabular}

Berdasarkan klasifikasi hasil tabel dan peta curah hujan di daerah penelitian, dapat di ketahui bahwa daerah penelitian memiliki intensitas hujan sebesar $1500-2000$ $\mathrm{mm} /$ tahun yang mencakup seluruh desa di Kecamatan Gedangsari. Sedangkan daearah Kecamatan Gantiwarno, Wedi, dan Bayat memiliki intensitas curah hujan sebesar 1000 $-1500 \mathrm{~mm} /$ tahun.

\subsection{Peta Jenis Tanah Daerah Penelitian}

Jenis tanah di daerah Kecamatan Gedangsari berdasarkan Peta Jenis Tanah Kabupaten Gunungkidul terbagi dalam empat jenis yaitu, tanah mediterania, tanah latosol merah, tanah litosol, dan tanah rendzina. Jenis tanah yang paling mendominasi adalah jensi tanah litosol yang berada di bagian utara kecamatan gedangsari. Perbedaan jenis tanah ini mempengaruhi kapasitas infiltrasinya. Dalam aspek tanah longsor, permeabilitas suatu tanah akan mempengaruhi kerentanan tanah longsornya. Semakin tinggi permeabilitasnya, kondisi tanah akan semakin jenuh dan akan semakin membebani tanah yang dapat memicu terjadinya gerakan massa tanah/longsor. Adapun untuk hasil peta kelerengan dan pembobotannya secara umum dapat di lihat pada (Gambar 7) dan (Tabel 7).

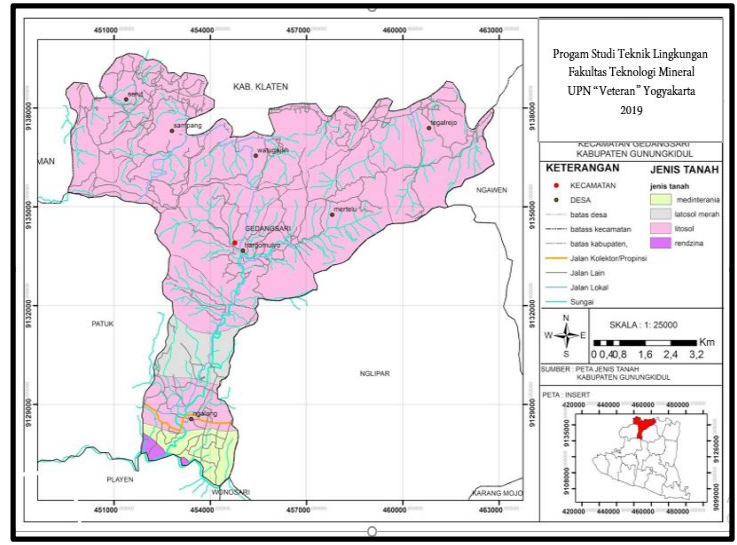

Gambar 7. Peta Jenis Tanah Daerah Kecamatan Gedangsari dan sekitarnya

Tabel 7. Nilai Pembobotan Jenis Tanah Kecamatan Gedangsari dan Sekitarnya

\begin{tabular}{|c|c|c|}
\hline No & Jenis Tanah & Nilai (skor) \\
\hline 1 & Tanah Litosol & 4 \\
\hline 2 & Tanah Rendzina & 3 \\
\hline 3 & Tanah Mediteran & 2 \\
\hline 4 & Latosol Tanah Merah & 1 \\
\hline
\end{tabular}

Berdasarkan klasifikasi Puslittanak 2004, pembobotan tanah di dasarkan dari tingkat kepekaan tanah terhadap erosi, maka di lokasi penelitian di bagi menjadi empat kelas yaitu, sangat peka/ permeabilitas sangat rendah (litosol), peka/permeabilitas rendah, agak peka/permeabilitas sedang (mediteran), dan tidak peka/permeabilitas tinggi (latosol tanah merah). Semakin tinggi permeabilitasnya, maka pembobotannya akan semakin besar.

\subsection{Analisis Potensi Pemukiman Risiko Rawan Tanah Longor Daerah Penelitian}

Dibawah ini merupakan kelas beserta rentang nilai yang digunakan untuk pembagian potensi pemukiman rawan tanah longsor dengan model Puslittanak (2004) yang telah di sesuaikan dengan karakteristik daerah penelitian

Tabel 8. Klasifikasi Daerah Rawan Longsor Kecamatan Gedangsari dan Sekitarnya

\begin{tabular}{|c|c|c|}
\hline No & Total Skor & Klasifikasi \\
\hline 1 & $<1,7$ & Tidak Rawan \\
\hline 2 & $1,7-2,5$ & Agak Rawan \\
\hline 3 & $2,6-3,4$ & Cukup Rawan \\
\hline
\end{tabular}




\begin{tabular}{|c|c|c|}
\hline 4 & $3,5-4,3$ & Rawan \\
\hline 5 & $>4,3$ & Sangat Rawan \\
\hline
\end{tabular}

Adapun hasil dari pembuatan overlay peta kerawanan tanah longsor dan peta pemukiman rawan longsor Kecamatan Gedangsari menggunakan metode Arc Gis 10.2 dengan skala peta $1: 25.000$ adalah :

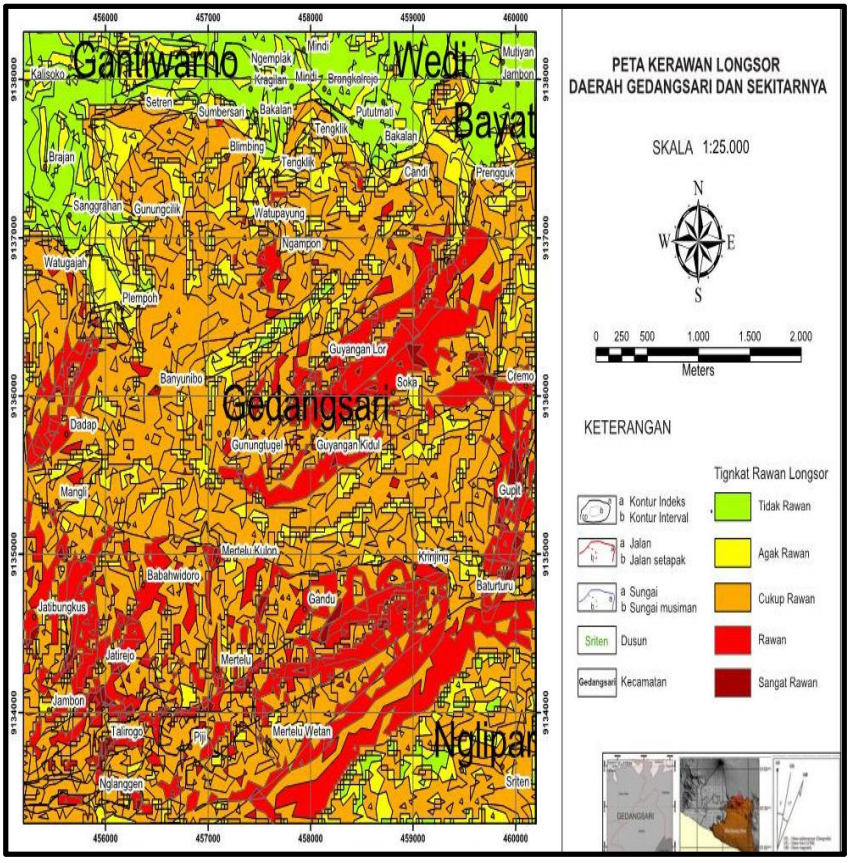

Gambar 8. Peta Kerawanan Longsor Daerah Kecamatan Gedangsari dan sekitarnya

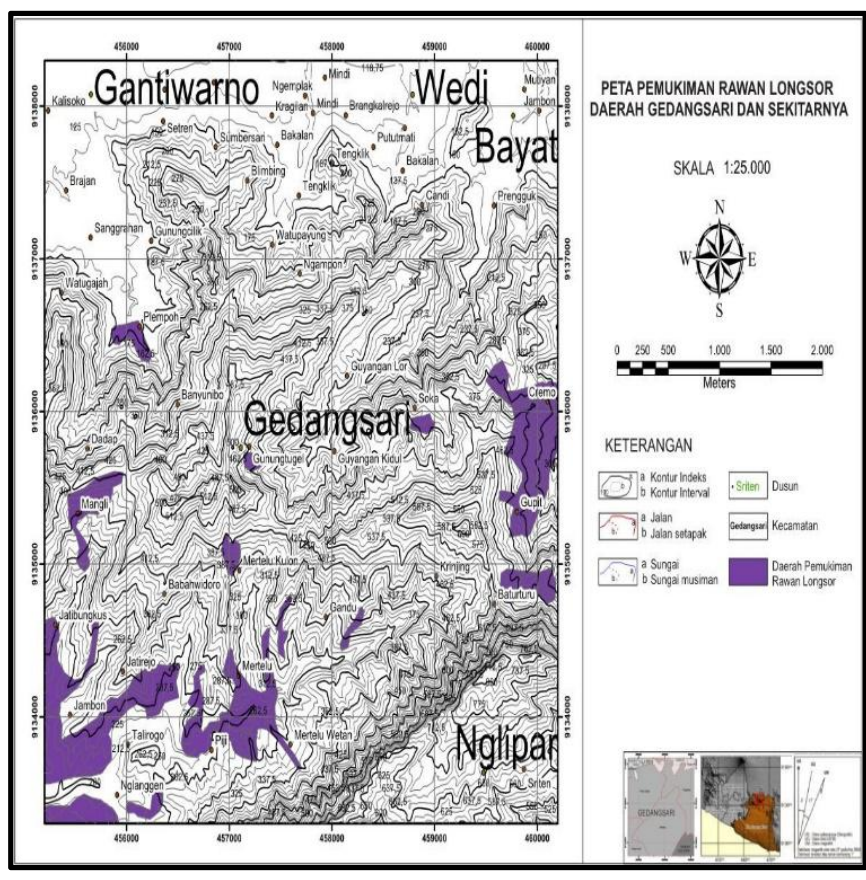

Gambar 9. Peta Pemukiman Rawan Longsor Daerah Kecamatan Gedangsari dan sekitarnya
Hasil peta kerawanan longsor tersebut, kemudian di aplikasikan untuk mengetahui potensi daerah pemukiman yang berkemungkinan masuk kedalam daerah rawan longsor. Analisi peta pemukiman rawan longsor di lakukan dengan membandingkan peta tata guna lahan yang ada, kemudian membuat zonasi pemukiman rawan tanah longsor pada wilayah Kecamatan Gedangsari. Adapun kenampakan peta rawan longsor dan peta pemukiman rawan longsor dapat di lihat di (Gambar 8) dan (Gambar 9).

Berdasarkan peta pemukiman rawan longsor menunjukkan bahwa pemukiman yang berada di sebelah timur dan barat daya peta memiliki potensi terkena bencana longsor lebih tinggi. Wilayah pemukiman rawan longsor ini meliputi beberapa Dusun diantaranya yaitu, Dusun Cremo, Dusun Gupit, dan Dusun Baturturu yang terletak didaerah timur peta, serta Dusun Mertelu dan sekitarnya yang terletak di daerah barat daya merupakan daerah yang berpotensi terjadi bencana tanah longsor. Sebagaimana diketahui wilayah pemukiman tersebut beresiko tanah longsor karena termasuk daerah yang memiliki kelerengan "curam" keatas, terdapat zona aktif struktur, dan curah hujan tinggi. Kondisi kelerengan yang terjal akan menyebabkan kondisi lereng menjadi tidak stabil dan rawan longsor. Kondisi geologi yang terdapat zona aktif struktur juga dapat mempengaruhi tingkat kerentanan longsor, terutama pada zona-zona struktur. Curah hujan yang cukup tinggi pada suatu wilayah juga dapat menyebabkan semakin tinggi potensi untuk terjadi longsor, hal ini di karenakan salah satu faktor pemicu terjadinya tanah longsor yaitu curah hujan dengan intensitas yang tinggi.

\section{KESIMPULAN}

Daerah Kecamatan Gedangsari dan sekitarnya merupakan daerah yang memiliki potensi rawan tanah longsor dikarenakan morfologi daerah tersebut yang curam dan juga jenis batuan dan zona struktur yang mendukung. Oleh karena itu perlu di lakukan pemetaan daerah rawan longsor dengan metode pembobotan yaitu dengan cara overlay seluruh parameter yang digunakan meliputi data kelerengan, curah hujan, zona struktur, jenis batuan, dan tata guna lahan 
daerah penelitian, yang masing- masing memiliki nilai pembobotan sendiri yang di sesuaikan dengan karakteristik daerahnya masing-masing.

Hasil analisis terhadap pemukiman risiko rawan longsor di Kecamatan Gedangsari dan sekitarnya memiliki hasil pembobotan potensi rawan longsor menjadi lima kelas yaitu: sangat rawan, rawan, cukup rawan, agak rawan, tidak rawan.Hasil analisis peta potensi rawan longsor dan peta pemukiman penduduk daerah Gedangsari dan sekitarnya menunjukkan adanya potensi bencana tanah longsor pada pemukiman di Dusun Cremo, Dusun Gupit, Dusun Baturturu pada daerah timur serta di Dusun Mertelu , Jatibungkus dan sekitarnya pada daerah barat daya.

\section{UCAPAN TERIMA KASIH}

Ucapan terimakasih disampaikan kepada Ketua Jurusan Teknik Lingkungan, UPN "Veteran" Yogyakarta, Aditya Pandu Wicaksono, S.Si.,M.Sc yang telah memberikan kesempatan kepada saya untuk melakukan kajian ilmiah, serta mas Joko Purwanto, dkk serta instansi terkait yang telah ikut membantu dalam penyediaan data lapangan di Kecamatan Gedangsari.

\section{DAFTAR PUSTAKA}

Badan Nasional Penanggulangan Bencana Daerah Kabupaten Gunungkidul., 2001. Penelitian Daerah Rawan Longsor dan Penanggulangannya di Kabupaten Gunungkidul, Laporan Akhir, BAPPEDA Gunungkidul.

Badan Nasional Penanggulangan Bencana Daerah Kabupaten Gunungkidul., 2016. Informasi Bencana Tanah Longsor. Laporan Akhir BPBD Gunungkidul.

Demers, M.N., 1997. "Fundamentals of Geographic Information Systems". New York : John Wileys \& Sons, Inc.

Kabupaten Gunungkidul, 2010. Rencana Tata Ruang Wilayah Kabupaten Gunungkidul Tahun 2010 - 2030. Gunungkidul : Sekretariat Daerah.

Nugroho, S. P., 2015. Relevansi Bencana Hidrometeorologi dan Kerusakan Das di Indonesia. Surakarta: Badan Nasional Penanggulangan Bencana.

Nurjanah. Dkk., 2011. Manajemen Bencana. Jakarta : Alfabeta.
Paimin, Sukresno dan Pramono, I. B., (2009). Teknik Mitigasi Banjir dan Tanah Longsor. Balikpapan: Tropenbos International Indonesia Programme.

Prahasta, Eddy., 2001. Konsep-Konsep Dasar Sistem Informasi Geografis (Perspektif Geodesi dan Geomatika). Bandung : Penerbit Informatika Bandung Putri.

Pusat Penelitian dan Pengembangan Tanah dan Agroklimat., 2004. Laporan Akhir Pengkajian Potensi Bencana Kekeringan, Banjir, dan Longsor di Kawasan Satuan Wilayah Sungai Citarum-Ciliwung, Jawa Barat Bagian Barat Berbasis Sistem Informasi Geografis. Bogor.

Rahardjo, W., Sukandarrumidi, \& Rosidi, H. D., 1995. Peta Geologi Lembar Yogyakarta, dan Jawa, Skala 1: 100.000. Bandung : Pusat Penelitian dan Pengembangan Geologi.

Undang-Undang Republik Indonesia tentang Penanggulangan Bencana, UndangUndang No. 24 Tahun 2007.

Yukni, Arifianti., 2011. Mengenal Lebih Dekat Tanah Longsor. Bandung: Pusat Vulkanologi dan Mitigasi Bencana Geologi. 